\title{
The role of probiotics in inhibition mechanism of methicillin-resistant staphylococcus aureus
}

\author{
Mahsa Abbasi $^{1}$ | Samaneh Dolatabadi ${ }^{2}$ | Ghazaleh Ghorbannezhad ${ }^{1}$ | \\ Fatemeh Sharifi $^{3}$ | Hamid Reza Rahimi ${ }^{4}$
}

\author{
${ }^{1}$ Student Research Committee, Faculty of \\ Medicine, Mashhad University of Medical \\ Sciences, Mashhad, Iran \\ ${ }^{2}$ Department of Microbiology, Faculty of \\ sciences, Neyshabur Branch, Islamic Azad \\ University, Neyshabur, Iran \\ ${ }^{3}$ Department of Optometry, School of \\ Paramedical Sciences, Mashhad University \\ of Medical Sciences, Mashhad, Iran \\ ${ }^{4}$ Neurogenic Inflammation Research Center, \\ Mashhad University of Medical Sciences, \\ Mashhad, Iran

\section{Correspondence} \\ Hamid Reza Rahimi \\ Email: RahimiHR@mums.ac.ir \\ Publication Date \\ July 30, 2020
}

MJM 2020 (18) 11

\section{\$. McGill \\ Journal of Medicine}

www.mjmmed.com

\section{(i) (2)}

This work is licensed under a Creative Commons BY-NC-SA 4.0 International License.

\section{ABSTRACT}

Down-regulation of the mecA gene is considered as a promising approach to control over antibiotic resistance in methicillin resistant Staphylococcus aureus (MRSA). This in vitro study evaluated the ability of synbiotics to inhibit the growth of MRSA and modify the expression of mecA. Moreover, susceptibility testing was performed to investigate synbioticinduced changes in MRSA resistance. MRSA isolates were collected from different clinical specimens and explored for antibiotic susceptibility using both disk-agar diffusion method as well as polymerase chain reaction (PCR) for detection of mecA gene. Synbiotics in the form of Kidilact ${ }^{\circledR}$, Vitalact ${ }^{\circledR}$, and Protexin ${ }^{\circledR}$ sachets were applied to prepare cell-free culture supernatants. Their antibacterial activity was determined by disk and well diffusion methods. The impact of synbiotics on the expression of mecA that denotes penicillin susceptibility was tested by real time PCR. It was shown that the synbiotics produced components with antimicrobial activities against MRSA. The supernatant produced by synbiotics can afford to confer penicillin susceptibility in the MRSA isolates in a timedependent fashion. Two third of susceptible MRSA isolates carried decreased levels of mecA expression. In conclusion, synbiotics are effective for reducing MRSA growth and antibiotic resistance through suppression of mecA.

\section{KEYWORDS}

Methicillin-resistant Staphylococcus aureus (MRSA), probiotics, mecA gene, synbiotics, antibacterial activity, penicillin susceptibility 


\section{1 | INTRODUCTION}

Staphylococcus aureus is considered as a commensal micro-organism that can cause hospital and communityacquired infections, namely, skin wound, sepsis, endocarditis, and pneumonia (1). Antibiotic therapy appear frequently ineffective because of emerging antibioticresistant strains, including methicillin-resistant $\mathrm{S}$. aureus (MRSA), which becomes prevalent in hospitals across the globe (2-5), imposes medical and socio-economic burden for both patients and health care providers, and contributes to morbidity and mortality (6). It has been reported that $S$. aureus respectively affects 12 million and 292,000 patients attending outpatient clinics and hospitals. As many as 126,000 present with MRSA infection each year in the United States (7). More importantly, an approximate of 90,000 Americans is estimated to die owing to hospital-acquired bacterial infections (8). As documented, the antimicrobial resistance appears to be a natural biological phenomenon that can be augmented by various factors, such as human practices. Indeed, the administration of antimicrobial agents against any pathogens leads them to either adapt or die (selective pressure). In so doing, those surviving carry genes for resistance, which can be transferred upon bacterial replication (9). The resistance in MRSA arises from the expression of Penicillin binding protein (PBP2a) encoded by mecA genes $(10,11)$.

There have been two main microbial approaches to manage antimicrobial resistance, including bacteriophage-based therapies as well as microbiome restoration. The former strategy deals with the application of phage or its component proteins however some have concerns over immunogenicity and bacterial resistance to bacteriophages $(12,13)$. The latter focuses on different mechanisms to decolonize antibiotic-resistant bacteria. Recent efforts have been directed towards the positive effects of probiotics on fecal microbiota $(14,15)$. Probiotics are beneficial micro-organisms that its consumption in adequate amounts promotes human health and affords protection against a variety of diseases (16). The use of these bacteria has been observed to ameliorate symptoms of gastrointestinal infections, prevent the growth of pathogenic strains, regulate the mucosal physiology or strengthen the intestinal immunity in hosts (17-20). Of note, supernatants released by multiple probiotics display inhibitory activity against different pathogens $(21,22)$. Chen et al. found that supernatants secreted by L. fermentum, B. longum subsp. longum, and B. animalis subsp. lactis could successfully deactivate MRSA (23). Of bacterial genera widely utilized in probiotic preparations, Lactobacillus, Bifidobacterium, Escherichia, Enterococcus, Bacillus, and Streptococcus have attracted more attention (24-26). The first group includes those strains producing lactate and lactic acid as the main end-product. Lacto-bacillus rhamnosus GG is a well-known probiotic that has been extensively investigated hitherto $(27,28)$. In general, lactobacilli, bifidobacteria, and lactococci are shown as safe considering their long history of use in food processing and dairy production (29). Though a rare case, no extant evidence has been recorded to date concerning any high risk of developing bacteremia or endocarditis following intake of probiotics (30, 31). The mechanisms whereby probiotics carry out their physiological role are chiefly contingent on the features, manufacturing, and formulation of the used strains (32) however the following processes have been observed to be involved as a result of probiotic treatment (33): competition for the ability of pathogens to colonization in the gastrointestinal tract through limiting their adhesion sites and/or nutrients $(34,35)$; biosynthesis of inhibitory metabolites, including organic acids and bacteriocins that improve peristalsis, inhibit the growth of pathogens or indirectly exclude them (36-39); immunomodulatory effects on the host $(35,37$, 40-42); and counteraction of bacterial toxins (43).

A body of literature has been conducted on the antagonistic interactions between probiotics and S. aureus/MRSA (44-49); for example, Karska-Wysocki et al. used a commercial probiotic (Bio- $\left.\mathrm{K}+{ }^{\circledR}\right)$ containing Lactobacillus acidophilus CL1285 ${ }^{\circledR}$ and Lactobacillus casei $\mathrm{LBC} 80 \mathrm{R}^{\circledR}$ in an in vitro setting to examine its inhibitory activities of against the growth of standard ATCC MRSA strain 43300 and human clinical isolates 
of MRSA by means of solid agar diffusion and liquid medium methods (50). It was indicated that L. acidophilus $\mathrm{CL} 1285^{\circledR}$ or L. casei $\mathrm{LBC}^{\circledR}{ }^{\circledR}$ caused an inhibition of MRSA growth, but to a different extent, with the former showing a zone diameter of $1.7-2.9 \mathrm{~cm}$ and the latter $1.4-2.9 \mathrm{~cm}$ depending on the MRSA clinical isolate. Direct interaction between Bio- $\mathrm{K}+{ }^{\circledR}$ and MRSA in liquid medium resulted in the elimination of almost all MRSA cells (99\%). The effects of acidic supernatants of $\mathrm{L}$. acidophilus isolated from a vinegar were explored against clinical MRSA samples related to acne pimple with lipolytic activity (45). It was exhibited that cellfree supernatant notably impacted MRSA isolates versus control. Subinhibitory concentrations of acid supernatants appeared very effective in preventing the lipase release from biofilm and planktonic cells of MRSA isolates (51). More to the point, prebiotics are nondigestive food constituents with selective actions on the growth and/or activity of one or more bacterial strains in the colon that culminate in health promoting effects $(52,53)$. The synergistic administration of probiotics and prebiotics is known as synbiotics (52). Given several possible combinations, the use of synbiotics for the regulation of intestinal microbiota in humans is expected to have promising outcomes (54). This study was an attempt to investigate the effect of synbiotics in the form of Kidilact ${ }^{\circledR}$, Vitalact ${ }^{\circledR}$, and Protexin ${ }^{\circledR}$ sachets on the growth of clinical MRSA isolates and expression of mecA gene.

\section{MATERIALS AND METHODS}

\section{1 | Samples Collection}

MRSA isolates from clinical specimens, including, blood, urine, sputum, wound, and lung tissue, were gathered from July to September 2015 from two main general hospitals affiliated to Mashhad University of Medical Sciences, Mashhad, Iran. All MRSA isolates were identified by routine laboratory procedures, such as, Gram stain, catalase test, oxidase test, coagulase activity, and mannitol salt fermentation (55). The antibiotic susceptibility of isolated strains was explored using the disk-agar diffusion method (56).

\subsection{Detection of mecA Gene in Clinical MRSA Isolates}

DNA extraction was conducted by Sinaclone DNA extraction kit (Sinaclon, Iran). Bacterial pellet was resuspended in $100 \mu \mathrm{l}$ of $\mathrm{G}+$ pre lysis buffer as well as $20 \mu \mathrm{l}$ of lyzosyme, and subsequently mixed and incubated at $37^{\circ} \mathrm{C}$ for $35 \mathrm{~min}$. After adding $20 \mu \mathrm{l}$ of ributinase, the solution underwent another incubation (at $55^{\circ} \mathrm{C}$ for 35 min) for complete cell lysis. Thereafter, lysis buffer as well as precipitation solution were added and the final mixed solution was loaded into a spin column. Following three wash steps, DNA was eluted by elution buffer in $65^{\circ} \mathrm{C}(57,58)$. To amplify mecA gene, the following forward and backward primers were respectively selected: 5'-AAAATCGATGGTAAAGGTTGGC and 5'-

\begin{tabular}{ccc}
\hline Kidilact ${ }^{\circledR}$ & Vitalact ${ }^{\circledR}$ & Protexin $^{\circledR}$ \\
\hline Lactobacillus Casei & Lactobacillus gasseri & Lactobacillus Casei $^{\circledR}$ \\
Lactobacillus acidophilus & Bifidobacterium bifidum & Lactobacillus acidophilus \\
Lactobacillus rhamnosus & Bifidobacterium longum & Lactobacillus rhamnosus \\
Lactobacillus bulgaricus & Lactobacillus bulgaricus \\
Bifidobacterium infantis & Bifidobacterium infantis \\
Bifidobacterium breve & Bifidobacterium breve \\
Streptococcus thermophilus & Streptococcus thermophilus \\
\hline
\end{tabular}

TABLE 1 The bacterial strains in each synbiotic supplement. 
AGTTCTGCAGTACCGGATTTGC). Genomic DNA was analyzed for the presence of the mecA gene employing the PCR system (Astec, Japan). The PCR products were visualized (UV duct, USA) under the UV transillumination after electrophoresis on $1.5 \%$ agarose gel containing Green viewer.

\section{3 | Probiotic Strains and Growth Conditions}

Synbiotics in the form of Kidilact $^{\circledR}$, Vitalact ${ }^{\circledR}$ (Zisttakhmir Company, Iran), and Protexin ${ }^{\circledR}$ (Science and Nature in Balance Company, UK) sachets were purchased. Each sachet contained 109 CFU probiotic strains. The bacteria used for the synbiotic supplements are shown in Table 1.

The pre-culture preparation is of utmost importance for providing optimal conditions for the bacteria to show their ability of releasing anti-MRSA components. Prior to analyses of anti-MRSA activity, these sachets were dissolved in normal saline $(2 \mathrm{~mL})$, added to brain-heart infusion broth (BHI; $5 \mathrm{~mL}$ ), and then incubated at $37^{\circ} \mathrm{C}$ for $24 \mathrm{~h}$. Afterwards, a $9 \mathrm{~mL}$ of each synbiotic supplement was subcultured on Man-Rogosa-Sharpe (MRS) broth to adapt them to the growth conditions during incubation for $24 \mathrm{~h}$ at $37^{\circ} \mathrm{C}$. Routine laboratory procedures (i.e., Gram stain, catalase test, coagulase activity, and motility) were carried out for these strains, as well. Cell-free culture supernatant was obtained by centrifugation at $5000 \mathrm{rpm}$ for $15 \mathrm{~min}$ at $4{ }^{\circ} \mathrm{C}$, as well as filtration using a $0.2 \mu \mathrm{m}$ syringe filter.

\subsection{Assessment of Bacteria Antagonistic Activities as Probiotics}

Disk diffusion. Initially, the supernatants at $\mathrm{pH} 4.0$ were neutralized to $\mathrm{pH} 7.0$ by $\mathrm{NaOH}(0.1 \mathrm{~N})$. Then, four test pathogens cultured in BHI agar were used. Spread culture of the bacterial suspensions were subsequently prepared on an agar plate using a turbidity equivalent to 0.5 McFarland standards. The plates were allowed to incubate for $30 \mathrm{~min}$ at $37^{\circ} \mathrm{C}$. A $20 \mu \mathrm{l}$ of each supernatant was loaded onto a $6 \mathrm{~mm}$ sterile disk. Three disks were separately put on the plate and maintained at $4{ }^{\circ} \mathrm{C}$ for 30 min to facilitate the diffusion of the loaded compounds. Another disk loaded by water was considered as the negative control. They were transferred into an incubation at $37^{\circ} \mathrm{C}$ for $24 \mathrm{~h}$, afterwards. Finally, the inhibition zone diameters were evaluated in triplicate.

Well diffusion. After neutralizing the supernatants as described in disk diffusion method, MRSA cultures were diluted to a suitable turbidity. The bacterial inoculum suspension was spread by swabbing on a $\mathrm{BHI}$ agar plate, which was subsequently allowed to dry at $37^{\circ} \mathrm{C}$ for $30 \mathrm{~min}$. A sterile Pasture pipette was applied to punch three wells, $9 \mathrm{~mm}$ in diameter, on the surface of agar. $130 \mu \mathrm{l}$ of each supernatant was poured inside the wells before incubation at $37^{\circ} \mathrm{C}$ for $24 \mathrm{~h}$. A vancomycin disk served as the positive control. The antimicrobial effect of each supernatant was expressed as the inhibition zone diameter in millimeter around the wells.

\section{5 | Penicillin-Susceptibility Testing}

Disk diffusion test was carried out on Mueller-Hinton agar plates with a penicillin disk (Padtan Teb, Iran). MRSA strains were incubated for $24 \mathrm{~h}$ at $37^{\circ} \mathrm{C}$. This test was iterated for 48, 72, 96, $120 \mathrm{~h}$. The zone diameter was measured in triplicate. Strains with the most susceptibility to penicillin were used for further analyses by real time $P C R$.

\begin{tabular}{llc}
\hline Length & $\mathbf{5}^{\prime} \rightarrow \mathbf{3}^{\prime}$ & Gene \\
\hline $199 \mathrm{bp}$ & ACTCCTACGGGAGGCAGCAGTGTATTACCGCGGCTGCTGGCA & 16s rRNA \\
$273 \mathrm{bp}$ & GATAAAAAAGAACCTCTGCTACTGCCTAATTCGAGTG & mecA
\end{tabular}

TABLE 2 mecA and 16s rRNA primers 


\section{$2.6 \quad$ Real Time PCR}

The bacterial RNA was extracted by the RNX-plus kit (Sinagene, Iran) as described by Morin et al (59). Purity and quality of the extracted RNA were assessed by NanoDrop spectrophotometer (Ipoch, China). Then, RNA underwent electrophoresis in a $2 \%$ agarose gel. Following purification steps, RNA was examined for the absence of protein, phenol, and genomic DNA through electrophoresis in a $1.5 \%$ agarose gel. Thereafter, complementary DNA (cDNA) was synthesized from RNA employing Easy cDNA Synthesis Kit (Parstoos, Iran) according to the manufacturer's instructions. The quality of cDNA was confirmed by PCR using mecA and 16s rRNA primers (Table 2). Quantitative analyses were carried out by means of SYBR Green Real Time PCR Master Mix (Parstoos, Iran) and Real-Time PCR System (ABlverity, USA). Each reaction mixture included $5 \mu$ l of master mix (2X), $1 \mu \mathrm{l}$ of cDNA, $6 \mu \mathrm{l}$ of dH2O, $0.2 \mu \mathrm{l}$ of ROX Reference Dye $(50 \mathrm{X})$, and $1 \mu \mathrm{l}$ of primer $(0.02 \mu \mathrm{M})$. The condition of PCR amplification contained an initial denaturation at $95^{\circ} \mathrm{C}$ for 7 minutes, followed by 40 cycles of denaturation for 30 seconds at $94^{\circ} \mathrm{C}$, annealing for 35 seconds at $45^{\circ} \mathrm{C}$, and extension for 40 seconds at $72^{\circ} \mathrm{C}$. The $2-\mathrm{Ct}$ method was applied to calculate the relative expression of mecA gene with $16 \mathrm{~s}$ rRNA as a housekeeping gene.

\section{3 | RESULTS}

\subsection{Collection of MRSA isolates}

The presence of $S$. aureus in all the clinical specimens was verified using a number of routine laboratory tests (Figures 1). A total of eight MRSA strains was isolated from various clinical specimens. As can be seen in Table 3 , these strains were shown to be resistant against most common antibiotics, including, ampicillin, oxacillin, erythromycin, cefoxitin, tetracycline, penicillin, gentamicin, and clindamycin. All strains developed sensitivity to vancomycin and ofloxacin, but resistance to ciprofloxacin. Only two samples ( $B$ and $C$ ) were sensitive to almost all antibiotics, thus they were excluded from the next experiments.

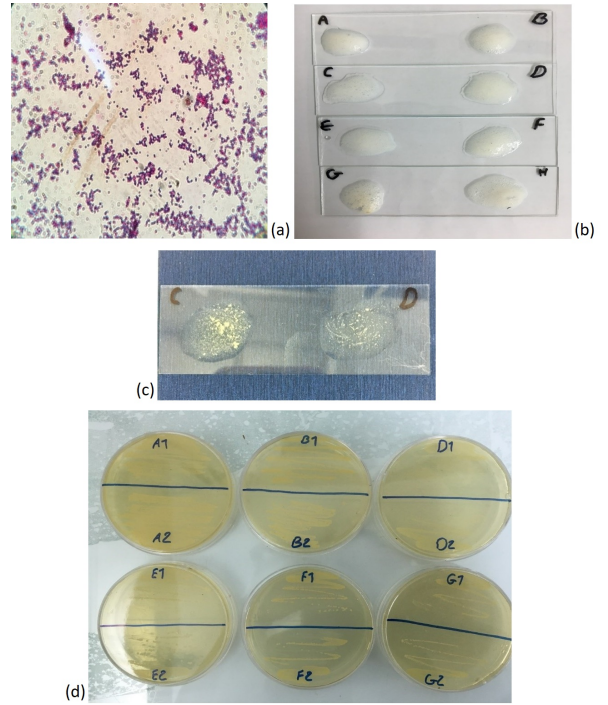

FIGURE 1 Identification of S. aureus by Gram stain (a), catalase test (b), coagulase activity (c), and monitol salt agar (d).

The genomic identity of the clinical MRSA isolates was substantiated through amplifying a 533 bp fragment of the mecA gene by the PCR analysis. Figure 2 demonstrated that six clinical isolates (A, D, E, F, G, and H) were PCR positive for mecA.

\subsection{Probiotic strains and their anti-MRSA properties}

The identification of probiotic strains in the commercial synbiotics was performed applying Gram stain (Figure 3a), coagulase test (Figure 3b), oxidase test (Figure 3c), and motility (Figure 3d). It appeared that these strains were Gram-positive, catalase-negative, oxidasenegative, and non-motile.

The antimicrobial activity of the supernatants produced by the commercial synbiotics is shown in Figure 4. Two different methods were used to test the antiMRSA potential of probiotics at $\mathrm{pH} 7.0$, wherein the lactic acid effects of components that may exist in the supernatants were removed. It was found that the disk diffusion method failed to indicate the inhibitory impacts of free-cell supernatants on MRSA isolates. There 


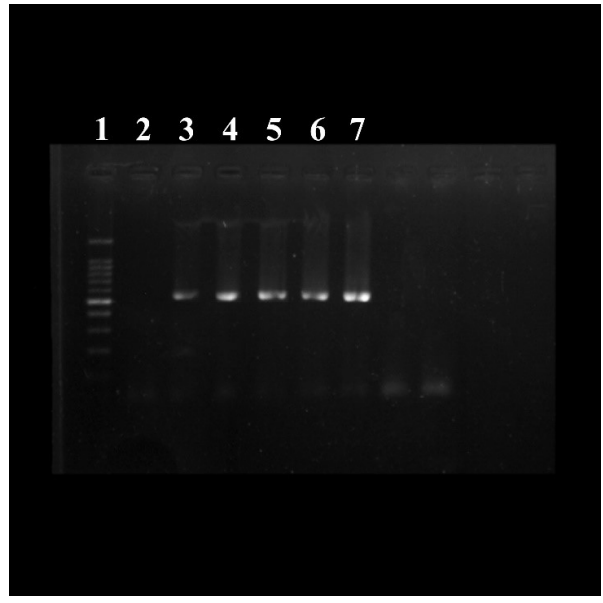

FIGURE 2 Agarose gel electrophoresis showing ladder (1), negative control (2), and samples D (3), E (4), $F(5), G(6)$ and $H(7)$.

was no obvious inhibitory zone and slight decreases occurred in the pathogen growth only on the surface of the plate (Figure 4a). On the contrary, the well diffusion method could obviously exhibit the anti-bacterial properties of the supernatants; the growth of MRSA in all sex isolates was inhibited as exposed to the supernatants (Figure 4b). Of note, the inhibition zone diameters of Protexin supernatant were greater than those of vancomycin. Table 4 summarizes the zone diameters of growth inhibition by the supernatants.

The inhibitory effects of the supernatants were also
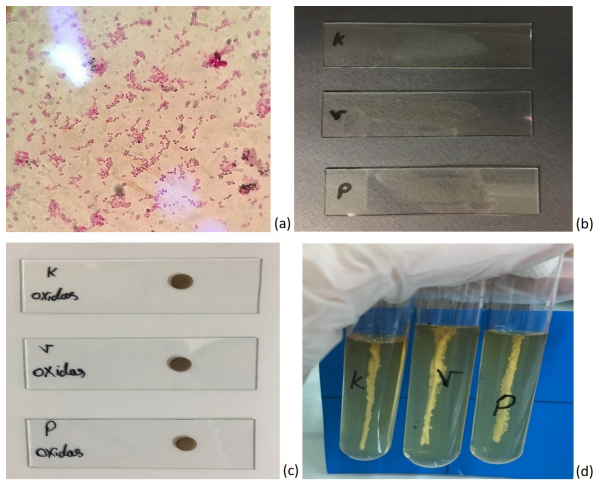

FIGURE 3 Identification of probiotics by Gram stain (a), coagulase test (b), oxidase test (c), and motility (d).

quantified using the following equation:

$$
x=\frac{\left(r_{2}^{2}-r_{1}^{2}\right) \times 100}{r_{1}^{2}}
$$

This denotes the comparative inhibition caused by the supernatants versus vancomycin. The positive values are indicative of the additional inhibition. Accordingly, Protexin supernatant induced an additional inhibition as opposed to vancomycin (Table 5).

\subsection{Penicillin susceptibility testing}

The results of penicillin-susceptibility testing presented that the supernatant produced by synbiotics can afford

\begin{tabular}{cccccccccccc}
\hline$*$ & $\mathrm{AM}$ & $\mathrm{OX}$ & $\mathrm{V}$ & $\mathrm{OFX}$ & $\mathrm{E}$ & $\mathrm{FOX}$ & $\mathrm{TE}$ & $\mathrm{P}$ & $\mathrm{GM}$ & $\mathrm{CC}$ & $\mathrm{CP}$ \\
\hline $\mathrm{A}$ & $\mathrm{R}$ & $\mathrm{R}$ & $\mathrm{S}$ & $\mathrm{S}$ & $\mathrm{R}$ & $\mathrm{R}$ & $\mathrm{R}$ & $\mathrm{R}$ & $\mathrm{R}$ & $\mathrm{R}$ & $\mathrm{R}$ \\
$\mathrm{B}$ & $\mathrm{S}$ & $\mathrm{S}$ & $\mathrm{S}$ & $\mathrm{S}$ & $\mathrm{S}$ & $\mathrm{S}$ & $\mathrm{S}$ & $\mathrm{S}$ & $\mathrm{S}$ & $\mathrm{S}$ & $\mathrm{R}$ \\
$\mathrm{C}$ & $\mathrm{S}$ & $\mathrm{S}$ & $\mathrm{S}$ & $\mathrm{S}$ & $\mathrm{S}$ & $\mathrm{S}$ & $\mathrm{S}$ & $\mathrm{S}$ & $\mathrm{S}$ & $\mathrm{S}$ & $\mathrm{R}$ \\
$\mathrm{D}$ & $\mathrm{R}$ & $\mathrm{R}$ & $\mathrm{S}$ & $\mathrm{S}$ & $\mathrm{R}$ & $\mathrm{R}$ & $\mathrm{R}$ & $\mathrm{R}$ & $\mathrm{S}$ & $\mathrm{R}$ & $\mathrm{R}$ \\
$\mathrm{E}$ & $\mathrm{R}$ & $\mathrm{R}$ & $\mathrm{S}$ & $\mathrm{S}$ & $\mathrm{R}$ & $\mathrm{R}$ & $\mathrm{R}$ & $\mathrm{R}$ & $\mathrm{S}$ & $\mathrm{R}$ & $\mathrm{R}$ \\
$\mathrm{F}$ & $\mathrm{R}$ & $\mathrm{R}$ & $\mathrm{S}$ & $\mathrm{S}$ & $\mathrm{R}$ & $\mathrm{R}$ & $\mathrm{R}$ & $\mathrm{R}$ & $\mathrm{S}$ & $\mathrm{R}$ & $\mathrm{R}$ \\
$\mathrm{G}$ & $\mathrm{R}$ & $\mathrm{R}$ & $\mathrm{S}$ & $\mathrm{S}$ & $\mathrm{R}$ & $\mathrm{R}$ & $\mathrm{R}$ & $\mathrm{R}$ & $\mathrm{S}$ & $\mathrm{R}$ & $\mathrm{R}$ \\
$\mathrm{H}$ & $\mathrm{R}$ & $\mathrm{R}$ & $\mathrm{S}$ & $\mathrm{S}$ & $\mathrm{R}$ & $\mathrm{R}$ & $\mathrm{R}$ & $\mathrm{R}$ & $\mathrm{S}$ & $\mathrm{R}$ & $\mathrm{R}$
\end{tabular}

TABLE 3 The inhibition zone of growth for MRSA strains by antibiotics. R: Resistance, S: Sensitive, AM: Ampicilin, OX: Oxacillin, V: Vancomycin, OFX: Ofloxacin, E: Erythromycin, FOX: Cefoxitin, TE: Tetracycline, P: Penicillin, GM: Gentamicin, CC: Clindamycin, CP:Ciprofloxacin. 

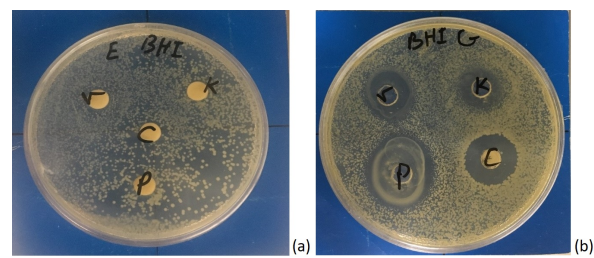

FIGURE 4 Different responses to antibiotics using the disk (a) and well (b) diffusion methods.

\begin{tabular}{|ccccc|}
\hline & Kidilact $^{\circledR}$ & Vitalact $^{\circledR}$ & Protexin $^{\circledR}$ & $\begin{array}{c}{ }^{\circledR} \\
\text {. }\end{array}$ \\
\hline A & 22 & 21 & 24 & 23 \\
\hline B & 15 & 13 & 18 & 18 \\
\hline D & 21 & 24 & 24 & 23 \\
\hline E & 12 & 22 & 28 & 22 \\
\hline F & 16 & 20 & 28 & 20 \\
\hline G & 16 & 19 & 29 & 19 \\
\hline H & 15 & 22 & 26 & 20 \\
\hline
\end{tabular}

TABLE 4 Different responses to antibiotics using the disk (a) and well (b) diffusion methods

to confer penicillin susceptibility in MRSA isolates at 72, 96, and $120 \mathrm{~h}$ (Figure 5). Therefore, the supernatants were observed to possess either bactericidal or bacteriostatic activities in a time-dependent fashion.

The penicillin zone diameters in MRSA isolates following 96 and $120 \mathrm{~h}$ co-culture with the supernatants are presented in Table 6. It was revealed that isolates A, D, and $E$ were the most susceptible samples at 120 $h$, while differently the other three isolates $(F, G$, and $H)$

\begin{tabular}{llll}
\hline & Kidilact $^{\circledR}$ & Vitalact $^{\circledR}$ & Protexin $^{\circledR}$ \\
\hline A & -8.5066 & -16.6351 & +8.8846 \\
D & -16.6351 & +8.8846 & +8.8846 \\
E & -70.2479 & 0 & +61.9833 \\
\hline F & -36.00 & 0 & +96.00 \\
\hline G & -29.0858 & 0 & +132.9639 \\
H & -0.4375 & +21.00 & +69.00
\end{tabular}

TABLE 5 The comparative inhibition caused by the supernatants versus vancomycin

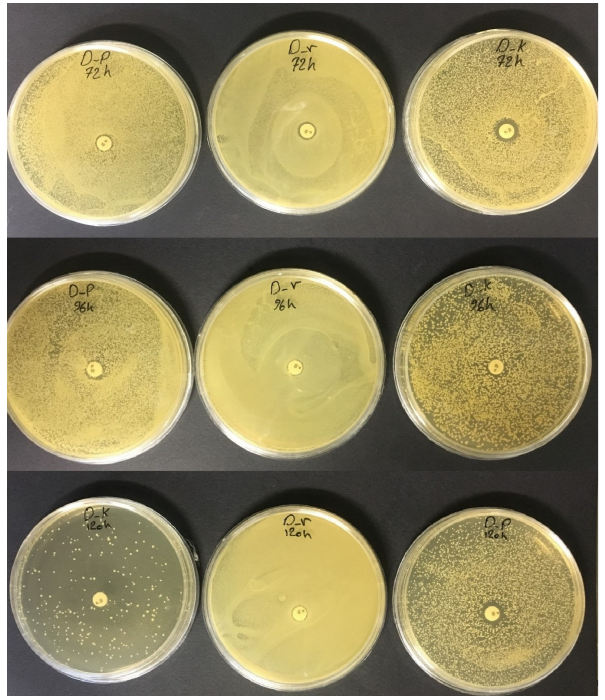

FIGURE 5 Penicillin susceptibility of MRSA isolates at different time points (72hrs,96hrs and 120hrs).

had the highest susceptibility at $96 \mathrm{~h}$. Moreover, the levels of susceptibility to penicillin caused by the supernatants are shown in Table 7. The neutralized supernatant of all three symbiotic supplements showed no activity against MRSA in isolates $G$ and $H$ after $120 \mathrm{~h}$. Unexpectedly, the neutralized supernatant of Kidilact $^{\circledR}$ was active against MRSA in isolate $F$ after $120 \mathrm{~h}$, whereas no activity was observed for that of Protexin ${ }^{\circledR}$.

\section{4 | DISCUSSION}

Commercial probiotics packed in one tablet or capsule are largely consumed across the globe. Considering the growing effects of antibiotic resistance, these dietary supplements have garnered more attention due to their potential against the spread of resistant determinants (60). This study aimed at elucidating whether cell-free supernatant from such dietary supplements can inhibit the growth of MRSA and affect their susceptibility to penicillin. The findings of this study indicated that the commercial synbiotics, including Kidilact $^{\circledR}$, Vitalact ${ }^{\circledR}$, and Protexin ${ }^{\circledR}$, produced components with antimicro- 


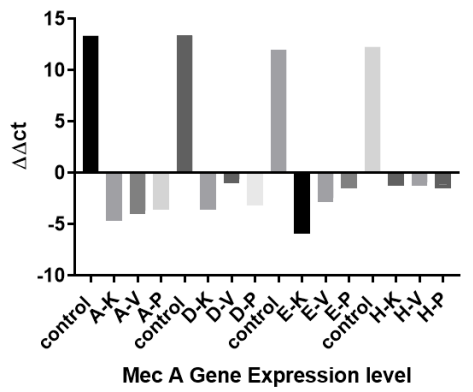

FIGURE 6 The expression level of mecA in different MRSA isolates following treatment with the supernatants of probiotics. A,D,E,H : MRSA isolates, $\mathrm{K}, \mathrm{V}, \mathrm{P}:$ Kidilact, Vitalact, Protexin. bial properties that can impede the growth of multiantibiotic resistance MRSA. This event was only manifest in the results of the well diffusion test. Moreover, the supernatant produced by synbiotics can afford to confer penicillin susceptibility in the MRSA isolates in a time-dependent fashion, which might be partly ascribed to the decreased expression of mecA gene. Indeed, two third of susceptible MRSA isolates carried declined levels of mecA gene expression. This is the first research study providing the in vitro evidence that supported the ability of the supernatant produced by commercial synbiotics not only to counteract against the MRSA isolates collected from clinical specimens, but also to induce penicillin susceptibility in these samples. The supernatant-reduced susceptibility mechanism of multiantibiotic resistance MRSA can be regulated through the expression of mecA gene. These findings were corroborated by Karska-Wysocki et al., whose study showed the bactericidal impact of mixed lactic acid bacteria (LAB) against MRSA. They concluded that the mixed cul-

\begin{tabular}{rccccc}
\hline$*$ & $96 h$ & $120 h$ & $*$ & $96 h$ & $120 h$ \\
\hline A-K & 9 & 6 & F-K & 7 & 6 \\
A-V & 8 & 8 & F-V & 8 & 7 \\
A-P & 7 & 6 & F-P & 10 & 0 \\
D-K & 5 & 8 & G-K & 9 & 0 \\
D-V & 8 & 6 & G-V & 0 & 0 \\
D-P & 7 & 12 & G-P & 6 & 0 \\
E-K & 13 & 13 & H-K & 7 & 0 \\
E-V & 7 & 14 & H-V & 10 & 0 \\
E-P & 8 & 9 & H-P & 7 & 0
\end{tabular}

TAB LE 6 The inhibition zone of growth for MRSA strains at different time points after co-culture with the supernatants.

\begin{tabular}{cccc}
\hline$*$ & $\begin{array}{c}\text { The levels of susceptibility to } \\
\text { penicillin }\end{array}$ & $*$ & $\begin{array}{c}\text { The levels of susceptibility to } \\
\text { penicillin }\end{array}$ \\
\hline A-K & 244.89 & F-K & 300 \\
\hline A-V & 359.18 & F-V & 359.18 \\
A-P & 244.89 & F-P & 489.79 \\
D-K & 359.18 & G-K & 422.44 \\
D-V & 244.89 & G-V & 0 \\
D-P & 636.73 & G-P & 244.89 \\
E-K & 716.32 & H-K & 300 \\
E-V & 800 & H-V & 489.79 \\
E-P & 422.44 & H-P & 300 \\
\hline
\end{tabular}

TAB LE 7 The levels of susceptibility to penicillin caused by the supernatants. 
ture of LAB strains contains several antibacterial components, which are not found in pure monoculture (50). Also, Matto et al. observed that a probiotic mixture containing several strains with distinct characteristics possessed the ability to effectively prevent infections caused by pathogenic bacteria (61). In addition to the production of organic acids (e.g., lactic acid), which has a lowering effect on $\mathrm{pH}$, certain strains can synthesize and secrete bioactive molecules, including ethanol, formic acid, fatty acids, hydrogen peroxide, and bacteriocins with marked antimicrobial actions (62). The genera Lactobacillus and Bifidobacterium along with their by-products have appeared to be effective for multiple conditions. Their antimicrobial activities arise from the inhibition of cellular functions through undesirable changes in the intracellular $\mathrm{pH}$ (63). The lack of activity against MRSA in isolates $G$ and $H$ could be justified by the effect of neutralized $\mathrm{pH}$ on the antagonistic activity of these probiotic bacteria in vitro. Therefore, the inhibition zones found despite the removal of lactic acid effects suggest the possible influences of other inhibitory by-products, namely hydrogen peroxide, bacteriocin and bacteriocin-like components (64). Given the findings of the present study, it was concluded that synbiotics are effective for reducing MRSA growth and antibiotic resistance through suppression of mecA.

\section{REFERENCES}

1. Malani PN, Rana MM, Banerjee M, Bradley SF. Staphylococcus aureus bloodstream infections: the association between age and mortality and functional status. Journal of the American Geriatrics Society. 2008;56(8):1485-9.

2. DeLeo FR, Otto M, Kreiswirth BN, Chambers HF. Communityassociated meticillin-resistant Staphylococcus aureus. The Lancet. 2010;375(9725):1557-68.

3. Otto M. Basis of virulence in community-associated methicillinresistant Staphylococcus aureus. Annual review of microbiology. 2010;64:143-62.

4. Chambers HF, DeLeo FR. Waves of resistance: Staphylococcus aureus in the antibiotic era. Nature Reviews Microbiology. 2009;7(9):629-41.

5. DeLeo FR, Chambers HF. Reemergence of antibiotic-resistant Staphylococcus aureus in the genomics era. The Journal of clinical investigation. 2009;119(9):2464-74.

6. Sachdev D, Amladi S, Natraj G, Baveja S, Kharkar V, Mahajan S, et al. An outbreak of methicillin-resistant Staphylococcus aureus (MRSA) infection in dermatology indoor patients. Indian Journal of Dermatology, Venereology, and Leprology. 2003;69(6):377.

7. Goetghebeur M, Landry P-A, Han D, Vicente C. Methicillinresistant Staphylococcus aureus: a public health issue with economic consequences. Canadian Journal of Infectious Diseases and Medical Microbiology. 2007;18(1):27-34.

8. Gilbert M, MacDonald J, Gregson D, Siushansian J, Zhang $\mathrm{K}$, Elsayed S, et al. Outbreak in Alberta of community-acquired (USA300) methicillin-resistant Staphylococcus aureus in people with a history of drug use, homelessness or incarceration. Canadian Medical Association Journal. 2006;175(2):149-54.

9. Berger-Bächi B. Resistance mechanisms of gram-positive bacteria. International Journal of Medical Microbiology. 2002;292(1):2735.

10. Zapun A, Contreras-Martel C, Vernet T. Penicillin-binding proteins and -lactam resistance. FEMS microbiology reviews. 2008;32(2):361-85.

11. Matsuhashi M, Song MD, Ishino F, Wachi M, Doi M, Inoue M, et al. Molecular cloning of the gene of a penicillin-binding protein supposed to cause high resistance to beta-lactam antibiotics in Staphylococcus aureus. Journal of Bacteriology. 1986;167(3):975-80.

12. Lu TK, Koeris MS. The next generation of bacteriophage therapy. Current opinion in microbiology. 2011;14(5):524-31.

13. Pires DP, Cleto S, Sillankorva S, Azeredo J, Lu TK. Genetically engineered phages: a review of advances over the last decade. Microbiology and Molecular Biology Reviews. 2016;80(3):523-43.

14. Donskey CJ. The role of the intestinal tract as a reservoir and source for transmission of nosocomial pathogens. Clinical infectious diseases. 2004;39(2):219-26.

15. Qin J, Li R, Raes J, Arumugam M, Burgdorf KS, Manichanh C, et al. A human gut microbial gene catalogue established by metagenomic sequencing. nature. 2010;464(7285):59-65.

16. Reid G. The importance of guidelines in the development and application of probiotics. Current pharmaceutical design. 2005;11(1):11-6.

17. Schrezenmeir J, de Vrese M. Probiotics, prebiotics, and synbiotics-approaching a definition-. The American journal of clinical nutrition. 2001;73(2):361s-4s.

18. Teitelbaum JE, Walker WA. Nutritional impact of pre-and probiotics as protective gastrointestinal organisms. Annual Review of Nutrition. 2002;22(1):107-38.

19. Agostoni C, Axelsson I, Goulet O, Koletzko B, Michaelsen KF, Puntis JW, et al. Prebiotic oligosaccharides in dietetic products for infants: a commentary by the ESPGHAN Committee on Nutrition. J Pediatr Gastroenterol Nutr. 2004;39:465-73.

20. Gaggìa F, Mattarelli P, Biavati B. Probiotics and prebiotics in animal feeding for safe food production. International journal of food microbiology. 2010;141:S15-S28.

21. Talarico T, Casas I, Chung TC, Dobrogosz W. Production and isolation of reuterin, a growth inhibitor produced by 
Lactobacillus reuteri. Antimicrobial agents and chemotherapy. 1988;32(12):1854-8.

22. Arqués JL, Fernández J, Gaya P, Nuñez M, Rodrıguez E, Medina M. Antimicrobial activity of reuterin in combination with nisin against food-borne pathogens. International journal of food microbiology. 2004;95(2):225-9.

23. Chen P-W, Jheng TT, Shyu C-L, Mao FC. Synergistic antibacterial efficacies of the combination of bovine lactoferrin or its hydrolysate with probiotic secretion in curbing the growth of meticillin-resistant Staphylococcus aureus. Journal of medical microbiology. 2013;62(12):1845-51.

24. Alvarez-Olmos MI, Oberhelman RA. Probiotic agents and infectious diseases: a modern perspective on a traditional therapy. Clinical infectious diseases. 2001;32(11):1567-76.

25. Gibson GR, Roberfroid MB. Dietary modulation of the human colonic microbiota: introducing the concept of prebiotics. The Journal of nutrition. 1995;125(6):1401-12.

26. Gupta V, Garg R. Probiotics. Indian journal of medical microbiology. 2009;27(3):202-9.

27. Goldin B, Gorbach S. Clinical indications for probiotics: an overview. Clinical Infectious Diseases. 2008;46(Supplement_2):S96-S100.

28. Gorbach SL. Probiotics and gastrointestinal health. The American Journal of Gastroenterology. 2000;95(1, Supplement 1):S2-S4. 29. Salminen S, von Wright A, Morelli L, Marteau P, Brassart D, de Vos WM, et al. Demonstration of safety of probiotics - a review. International journal of food microbiology. 1998;44(1):93-106.

30. Snydman DR. The safety of probiotics. Clinical infectious diseases. 2008;46(Supplement_2):S104-S11.

31. Sorokulova I. Preclinical testing in the development of probiotics: a regulatory perspective with Bacillus strains as an example. Clinical infectious diseases. 2008;46(Supplement_2):S92-S5.

32. Grześkowiak Ł, Isolauri E, Salminen S, Gueimonde M. Manufacturing process influences properties of probiotic bacteria. British Journal of Nutrition. 2011;105(6):887-94.

33. Bermudez-Brito M, Plaza-Díaz J, Muñoz-Quezada S, GómezLlorente C, Gil A. Probiotic mechanisms of action. Annals of Nutrition and Metabolism. 2012;61(2):160-74.

34. Lu L, Walker WA. Pathologic and physiologic interactions of bacteria with the gastrointestinal epithelium-. The American journal of clinical nutrition. 2001;73(6):1124S-30S.

35. Zhang L, Xu Y-Q, Liu H-Y, Lai T, Ma J-L, Wang J-F, et al. Evaluation of Lactobacillus rhamnosus GG using an Escherichia coli K88 model of piglet diarrhoea: Effects on diarrhoea incidence, faecal microflora and immune responses. Veterinary Microbiology. 2010;141(1):142-8.

36. Barefoot SF, Klaenhammer TR. Detection and activity of lactacin B, a bacteriocin produced by Lactobacillus acidophilus. Applied and Environmental microbiology. 1983;45(6):1808-15.

37. Kailasapathy K, Chin J. Survival and therapeutic potential of probiotic organisms with reference to Lactobacillus acidophilus and
Bifidobacterium spp. Immunology and Cell Biology. 2000;78(1):808.

38. Kopp-Hoolihan L. Prophylactic and therapeutic uses of probiotics: a review. Journal of the Academy of Nutrition and Dietetics. 2001;101(2):229-41.

39. Yamano T, lino H, Takada M, Blum S, Rochat F, Fukushima Y. Improvement of the human intestinal flora by ingestion of the probiotic strain Lactobacillus johnsoniiLa1. British Journal of Nutrition. 2006;95(2):303-12.

40. Ibnou-Zekri N, Blum S, Schiffrin EJ, von der Weid T. Divergent patterns of colonization and immune response elicited from two intestinal Lactobacillus strains that display similar properties in vitro. Infection and immunity. 2003;71(1):428-36.

41. Salminen S, Bouley C, Boutron M-C, Cummings J, Franck A, Gibson $\mathrm{G}$, et al. Functional food science and gastrointestinal physiology and function. British Journal of Nutrition. 1998;80(S1):S147-S71.

42. Schiffrin $\mathrm{E}$, Rochat $\mathrm{F}$, Link-Amster $\mathrm{H}$, Aeschlimann J, DonnetHughes A. Immunomodulation of human blood cells following the ingestion of lactic acid bacteria. Journal of Dairy Science. 1995;78(3):491-7.

43. Corthier G, Dubos F, Raibaud P. Modulation of cytotoxin production by Clostridium difficile in the intestinal tracts of gnotobiotic mice inoculated with various human intestinal bacteria. Applied and environmental microbiology. 1985;49(1):250-2.

44. Bendjeddou K, Fons M, Strocker P, Sadoun D. Characterization and purification of a bacteriocin from Lactobacillus paracasei subsp. paracasei BMK2005, an intestinal isolate active against multidrugresistant pathogens. World Journal of Microbiology and Biotechnology. 2012;28(4):1543-52.

45. Fahad HJ, Radeef HM. Capability of Lactobacillus acidophilus supernatant to inhibit production of lipase from methicillinresistant Staphylococcus aureus. J Univ Anbar Pure Sci. 2011;5:15.

46. Sadowska B, Walencka E, Wieckowska-Szakiel M, Różalska B. Bacteria competing with the adhesion and biofilm formation by Staphylococcus aureus. Folia microbiologica. 2010;55(5):497-501.

47. Charlier C, Cretenet M, Even S, Le Loir Y. Interactions between Staphylococcus aureus and lactic acid bacteria: an old story with new perspectives. International journal of food microbiology. 2009;131(1):30-9.

48. Prince T, McBain AJ, O'Neill CA. Lactobacillus reuteri protects epidermal keratinocytes from Staphylococcus aureus-induced cell death by competitive exclusion. Applied and environmental microbiology. 2012;78(15):5119-26.

49. Jones ML, Ganopolsky JG, Labbé A, Prakash S. A novel nitric oxide producing probiotic patch and its antimicrobial efficacy: preparation and in vitro analysis. Applied microbiology and biotechnology. 2010;87(2):509-16

50. Karska-Wysocki B, Bazo M, Smoragiewicz W. Antibacterial activity of Lactobacillus acidophilus and Lactobacillus casei against methicillin-resistant Staphylococcus aureus (MRSA). Microbiologi- 
cal research. 2010;165(8):674-86.

51. Sikorska H, Smoragiewicz W. Role of probiotics in the prevention and treatment of meticillin-resistant Staphylococcus aureus infections. International journal of antimicrobial agents. 2013;42(6):475-81.

52. Collins MD, Gibson GR. Probiotics, prebiotics, and synbiotics: approaches for modulating the microbial ecology of the gut. The American journal of clinical nutrition. 1999;69(5):1052s-7s.

53. Gibson GR, Beatty ER, Wang X, Cummings JH. Selective stimulation of bifidobacteria in the human colon by oligofructose and inulin. Gastroenterology. 1995;108(4):975-82.

54. Scavuzzi B, Henrique F, Miglioranza L, Simão A, Dichi I. Impact of prebiotics, probiotics and synbiotics on components of the metabolic syndrome. Ann Nutr Disord Ther. 2014;1:1009.

55. Merlino J, Watson J, Rose B, Beard-Pegler M, Gottlieb T, Bradbury $R$, et al. Detection and expression of methicillin/oxacillin resistance in multidrug-resistant and non-multidrug-resistant Staphylococcus aureus in Central Sydney, Australia. Journal of Antimicrobial chemotherapy. 2002;49(5):793-801.

56. McDougal LK, Thornsberry C. New recommendations for disk diffusion antimicrobial susceptibility tests for methicillin-resistant (heteroresistant) staphylococci. Journal of clinical microbiology. 1984;19(4):482-8.

57. Asgharzadeh M, Kafil HS, Roudsary AA, Hanifi GR. Tuberculosis transmission in Northwest of Iran: using MIRU-VNTR, ETRVNTR and IS6110-RFLP methods. Infection, Genetics and Evolution. 2011;11(1):124-31.

58. Toledo-Arana A, Valle J, Solano C, Arrizubieta MaJ, Cucarella C, Lamata $M$, et al. The enterococcal surface protein, Esp, is involved in Enterococcus faecalis biofilm formation. Applied and environmental microbiology. 2001;67(10):4538-45.

59. Morin NJ, Gong Z, Li X-F. Reverse Transcription-Multiplex PCR Assay for Simultaneous Detection of $<$ em $>$ Escherichia coli</em> O157:H7, <em>Vibrio cholerae</em> O1, and $<$ em $>$ Salmonella $</$ em $>$ Typhi. Clinical Chemistry. 2004;50(11):2037-44.

60. Broaders E, Gahan CG, Marchesi JR. Mobile genetic elements of the human gastrointestinal tract: potential for spread of antibiotic resistance genes. Gut microbes. 2013;4(4):271-80.

61. Mättö J, Fondén R, Tolvanen T, von Wright A, VilpponenSalmela T, Satokari R, et al. Intestinal survival and persistence of probiotic Lactobacillus and Bifidobacterium strains administered in triple-strain yoghurt. International dairy journal. 2006;16(10):1174-80.

62. De Vuyst L, Leroy F. Bacteriocins from lactic acid bacteria: production, purification, and food applications. Journal of molecular microbiology and biotechnology. 2007;13(4):194-9.

63. Kivanc M, Yilmaz M, Cakir E. Isolation and identification of lactic acid bacteria from boza, and their microbial activity against several reporter strains. Turkish Journal of Biology. 2011;35(3):313-24.
64. Georgieva R, Yocheva L, Tserovska L, Zhelezova G, Stefanova $\mathrm{N}$, Atanasova A, et al. Antimicrobial activity and antibiotic susceptibility of Lactobacillus and Bifidobacterium spp. intended for use as starter and probiotic cultures. Biotechnology Biotechnological Equipment. 2015;29(1):84-91. 